ROCZNIKI TEOLOGICZNE

Tom LXVIII, zeszyt 3 - 2021

DOI: https://doi.org/10.18290/rt.21683-7

EWA BANASZAK

\title{
TOWARZYSZENIE CZŁOWIEKOWI W OBLICZU ŚMIERCI. ASPEKTY MORALNE
}

\author{
ACCOMPANYING MAN IN THE FACE OF DEATH. MORAL ASPECTS.
}

A b s t r a c t. The key issue of the undertaken topic is accompanying the dying person. Death as the last phase of human life is an undeniable fact, and the transition to eternal life is an extremely important event for believers. Making it a human event amid medical procedures, fears and marginalization becomes the call of modern civilization. Recognition of the dying process becomes an important element in starting the preparation for death and accompanying you in this mystery. The responsibility of medical personnel for providing information about the possibility of death and preparing the patient and his family for the time of dying. Accepting death and accepting leaving this world becomes the basic indication of restoring the humanistic dimension to this event among medical procedures. The pandemic time, which makes it impossible for the family to relate to the sick, has become a particular symptom of the industrialization of dying. Pointing out the symptoms of the last phase of human life will allow the family and the dying person to recognize this time and at the same time begin the process of accompaniment. An important aspect in the reflection on accompanying the dying person is to show the family and loved ones specific skills useful in terminal care.

Keywords: humanization of death; thanatophobia; phases of dying; companionship; skills.

Jedną z ważnych potrzeb człowieka we współczesnym świecie jest potrzeba relacji. Człowiek potrzebuje wsparcia bliskiej osoby. Potrzeba obecności drugiej osoby w specyficzny sposób narasta w obliczu zagrożenia chorobą,

Ewa BANASZAK - mgr pielęgniarstwa, mgr teologii, doktorantka w Instytucie Nauk Teologicznych Katolickiego Uniwersytetu Lubelskiego Jana Pawła II, pracownik Centrum Onkologii Ziemi Lubelskiej im. św. Jana z Dukli; e-mail: ewakiecka@interia.pl; ORCID: https:// orcid.org/0000-0002-8228-0602. 
koniecznością hospitalizacji i leczenia operacyjnego. Wówczas poszukuje się w sposób niejako automatyczny wśród najbliższych osoby, która stanie się powiernikiem najskrytszych, często intymnych problemów związanych z sytuacją, w jakiej stawia człowieka choroba. W poczuciu bezsilności i braku możliwości realizacji samoopieki w zaspokajaniu podstawowych potrzeb, chory jest zmuszony prosić o pomoc i wsparcie w nowych niepewnych okolicznościach. Sytuacja nabiera dramatycznego wymiaru, kiedy stan zdrowia nie rokuje na poprawę, pobyt w szpitalu przedłuża się, a wydolność w zakresie samoobsługi zmniejsza się z każdym dniem ${ }^{1}$.

Zagadnienie towarzyszenia człowiekowi w obliczu śmierci łączy się z zadaniem przywrócenia temu wydarzeniu humanistycznego wymiaru zarówno wobec osoby umierającej, jak i jej najbliższych. W tym kontekście należy podjąć próbę podkreślenia doniosłości momentu śmierci, a równocześnie potrzeby towarzyszenia w procesie umierania. Kolejnym aspektem omawianego tematu będzie zwrócenie uwagi na rozpoznanie momentu odchodzenia z tego świata oraz zagadnienie przekazania informacji o bezskuteczności dalszego leczenia, z czym związany jest problem odpowiedzialności personelu medycznego za przekazanie informacji o możliwości śmierci oraz uwrażliwienie chorego i jego rodziny na czas umierania. W końcowej części badań zostanie przeanalizowana tematyka towarzyszenia osobie w misterium śmierci pod kątem przełamywania lęków tanatycznych poprzez modyfikację nastawienia do umierania. Ważnym elementem towarzyszenia umierającemu staje się przygotowanie rodziny do straty najbliższych oraz włączenie ich do opieki poprzez wskazanie na umiejętności przydatne w opiece terminalnej.

\section{HUMANIZACJA UMIERANIA}

Życie człowieka nieuchronnie zmierza ku przejściu do nowej rzeczywistości: chrześcijanie $\mathrm{w}$ świetle wiary umierają z Chrystusem, aby z Nim zmartwychwstać ${ }^{2}$. Umieranie jest naturalnym, nieuniknionym wydarzeniem każdego ludzkiego istnienia, jest misterium przejścia do wieczności, potwierdza to nauka Kościoła w soborowej Konstytucji duszpasterskiej o Kościele w świecie współczesnym Gaudium et spes: „Tajemnica losu ludzkiego ujawnia się najbardziej

\footnotetext{
${ }^{1}$ Por. Jarosław Sak, Wielowymiarowość postrzegania choroby w kontekście przekonań zdrowotnych i poczucia sensu życia (Lublin: Uniwersytet Medyczny, 2013), 51-2.

${ }^{2}$ Por. Katechizm Kościoła Katolickiego, Poznań: Pallottinum, 1994, nr 1005 [dalej: KKK].
} 
w obliczu śmierci”’3. Śmierć cielesna, będąca konsekwencją grzechu, jest ostatnim etapem zmagań ludzkich o wieczność w czasie ziemskiej wędrówki.

Chrystus, który jako pierwszy przeszedł zwycięsko przez śmierć zmartwychwstając do nowego życia, pozwala w niej widzieć błogosławieństwo i pozytywny sens ${ }^{4}$. Przez sakrament chrztu człowiek zanurzony w Misterium Chrystusa partycypuje w nowym życiu. Śmierć jest końcem ziemskiego pielgrzymowania, ale życie zmierza na spotkanie wieczności w domu Ojca. Bóg w śmierci wzywa nas do siebie na wieczną ucztę miłości, kładąc kres wierze i nadziei ${ }^{5}$. Perspektywa przejścia życia ludzkiego do wieczności, której progiem jest śmierć, wymaga przygotowania i przeżycia ${ }^{6}$.

Umieranie jest nieuniknionym procesem w życiu każdego człowieka. Następuje jako ostatnia faza ludzkiego istnienia. Jest to etap, w którym kończy się ziemskie życie, nadchodzi czas rozstania z najbliższymi, specyficznego pożegnania, bo ostatniego. Chwile związane z odejściem napełniają smutkiem, bezsilnością, dramatem rozstania i pożegnania. Dodatkowo wzrasta napięcie, gdy bliska nam osoba cierpi i odczuwa ból choroby, a towarzyszące jej osoby nie mogą poradzić sobie $\mathrm{z}$ narastająca frustracją, smutkiem i łzami ${ }^{7}$.

W obliczu śmierci wymagany jest zatem wyjątkowy szacunek, odpowiedzialność, poszanowanie godności ludzkiego odejścia, wrażliwość na spełnienie ostatnich próśb. Delikatna obecność i pełne miłości uwrażliwienie na każdy gest i spojrzenie odchodzącej osoby, pozwala stworzyć swoisty klimat dla kończącego się życia. Towarzyszyć osobie w obliczu śmierci oznacza bycie w trudnej chwili należącej jeszcze do życia, a jednocześnie będącej ostatnim etapem pielgrzymowania na ziemi ${ }^{8}$.

Pochylenie się nad człowiekiem, który przeżywa cierpienie w godzinie śmierci, często ogranicza się do modlitewnego czuwania i troskliwej obecności. Ważnym postulatem chrześcijańskiej miłości jest integralne spojrzenie na chorego, całkowite oddanie się posłudze obecności oraz współpraca z Bożą łaską i miłością ${ }^{9}$. Idealnym a zarazem jedynym właściwym miejscem umiera-

\footnotetext{
${ }^{3}$ KDK 18.

${ }^{4}$ Por. KKK 1009.

${ }^{5}$ Por. KKK 1010.

${ }^{6}$ Por. KKK 1011.

${ }^{7}$ Por. Sak, Wielowymiarowość postrzegania choroby w kontekście przekonań, 62-3.

${ }^{8}$ Por. Tadeusz Reroń, Etyka w szpitalu. Diakonia - Medycyna - Duszpasterstwo (Wrocław: Papieski Wydział Teologiczny, 2020), 180.

${ }^{9}$ Por. Janusz Nagórny, Wartość ludzkiego życia, red. Krzysztof Jeżyna, Jerzy Gocko, Wojciech Rzepa (Lublin: Wydawnictwo KUL, 2009), 17-20.
} 
nia jest atmosfera domu rodzinnego i obecność najbliższych kochających osób. Placówki szpitalne nie zawsze w odpowiedni sposób podejmują problem opieki nad umierającymi. Leczenie szpitalne obwarowane procedurami medycznymi nastawione jest na świadczenie usług medycznych prowadzących do poprawy stanu zdrowia przez wdrożenie odpowiedniego postępowania interwencyjnego. Sytuacja staje się newralgiczna, kiedy zastosowane metody lecznicze nie przynoszą pożądanych rezultatów. Stan chorego pogarsza się w sposób nieodwracalny i jego życie nieuchronnie zmierza ku końcowi ${ }^{10}$. Działania medyczne nastawione na efekt, osiągają kres i nie przynoszą oczekiwanych skutków. Wówczas pojawiają się nowe trudności związane z postawą i reakcją pracowników medycznych wobec sytuacji umierania i śmier$\mathrm{ci}^{11} . \mathrm{Z}$ jednej strony poważnym problemem staje się stosowanie metod uporczywej terapii, a z drugiej - postawa niehumanitarnego traktowania, zaniedbywania, obojętności i zgoda na eutanazję $e^{12}$.

Powstające problemy podczas opieki nad umierającymi w placówkach medycznych, często są generowane poprzez sformalizowane działanie: „Szpital odznacza się na ogół w warunkach współczesnych znacznym stopniem zbiurokratyzowania, sztywności działań, niezdolności do akomodacji przepisów i standardów do konkretnych sytuacji egzystencjalnych. Istotnym wydaje się także to, że szpital kieruje się często poprawnością działań, fragmentaryzacją leczenia, a wreszcie formalizacją relacji międzyludzkich"13. Rozważne stosowanie procedur medycznych oraz zapewnienie godnych warunków do umierania i śmierci staje się poważnym wezwaniem dla personelu ośrodków medycznych. Osoba nieuleczalnie chora, wkraczająca w fazę umierania, często pozbawiona jest szacunku i możliwości godnego, właściwego sobie sposobu odejścia z tego świata ${ }^{14}$.

Rozpoczyna się misterium umierania, przeplatane wewnętrznym rozdarciem, lękiem i niepewnością oraz nadzieją przejścia do lepszego, nieprzemijającego życia i spotkania $\mathrm{z}$ miłującym Ojcem ${ }^{15}$. Ten jakże bogaty $\mathrm{w}$ inten-

\footnotetext{
${ }^{10}$ Por. Antoni Bartoszek, Człowiek w obliczu cierpienia i umierania. Moralne aspekty opieki paliatywnej (Katowice: Księgarnia św. Jacka, 2000), 214.

${ }^{11}$ Por. Józef Wróbel, Człowiek $i$ medycyna. Teologicznomoralne podstawy ingerencji medycznych (Kraków: Wydawnictwo Księży Sercanów, 1999), 89-91.

12 Por. Wojciech Bołoz, „Eutanazja w kontekście praw człowieka”, w Bioetyka personalistycz$n a$, red. Tadeusz Biesaga (Kraków: Wydawnictwo Naukowe PAT, 2006), 337-54.

${ }^{13}$ Reroń, Etyka w szpitalu, 181.

${ }^{14}$ Por. tamże, 183.

${ }^{15}$ Por. Jan Paweł II, Encyklika o wartości i nienaruszalności życia ludzkiego „Evangelium vitae” (25.03.1995), Rzym 1995, nr 35 [dalej: EV].
} 
sywność przeżyć czas jest dla umierającego bardzo istotnym momentem, dlatego zamiast mnóstwa zabiegów uporczywie podtrzymujących przy życiu, wymagana jest profesjonalna opieka przedśmiertna ${ }^{16}$. Paradoksem współczesnej medycyny, budzącym problemy moralne, jest wydłużanie ludzkiego życia uporczywą terapią, co w gruncie rzeczy prowadzi do wydłużania procesu umierania. Człowiek ma zarówno prawo do godnego życia, jak i do godnego umierania. Podobnie jak nikt nie ma prawa odbierać życia śmiertelnie chorym przez eutanazję, tak nie ma prawa przedłużać za wszelką cenę gasnącego życia ${ }^{17}$.

Odstapienie od terapii medycznych w obliczu umierania nie zawsze jest decyzją łatwą do podjęcia, a czasem nawet niemożliwą do określenia w sposób całkowicie pewny. Wymaga to odpowiedniej wiedzy, doświadczenia, całościowego spojrzenia na danego człowieka, a nade wszystko znajomości jego samego, a nie tylko jako przypadku medycznego. Do kompetencji wykwalifikowanej kadry lekarzy i pielęgniarek należy rozpoznanie procesu umierania w celu poinformowania zarówno osoby umierającej, jak i jego rodziny, aby mogli przygotować się do rozstania, jakie niesie śmierć. Ważne jest, aby w procesie umierania nie zostawić człowieka samego, nawet gdy w poczuciu bezradności, onieśmielenia, a często w zmowie milczenia i bezsilności rodzi się pokusa, by unikać spotkania i rozmowy ${ }^{18}$.

Jan Paweł II w przemówieniu do uczestników Papieskiej Akademii „Pro Vita" podkreśla obowiązek poszanowania godności człowieka umierającego: „Kościół zabiera publicznie głos, aby nie poniżano godności umierającego, ale by otoczono go troskliwą miłością i opieką w chwili, gdy przygotowuje się do przekroczenia progu czasu i do wejścia w wieczność"19. Godne uwagi jest użyte przez Papieża określenie „troskliwą miłością”, które sugeruje przyjęcie szczególnej postawy, nacechowanej opieką w najwyższym stopniu delikatną, czułą i zatroskaną. Jest jednocześnie scharakteryzowaniem towarzyszenia umierającemu człowiekowi, które wymaga obecności, troski, miłości

\footnotetext{
${ }^{16}$ Bartoszek, Człowiek w obliczu cierpienia i umierania, 184.

${ }^{17}$ Por. Piotr Aszyk, Granice leczenia. Etyczny problem odstapienia od interwencji medycznych (Warszawa: Rhetos, 2006), 164.

18 Por. Janusz Anders, „Problemy medyczne i etyczne stanów terminalnych człowieka”, w Bioetyka personalistyczna, red. Tadeusz Biesaga (Kraków: Wydawnictwo Naukowe PAT, 2006), 326-36.

19 Jan Paweł II, „Godność człowieka umierającego”. Przemówienie do uczestników zgromadzenia ogólnego Papieskiej Akademii „Pro Vita” (27.02.1999), L'Osservatore Romano (pol.) 20, $\mathrm{nr} 3(1999)$.
} 
i opieki ${ }^{20}$. W obliczu braku szacunku i obojętności wobec umierającego, Ojciec Święty wzywa na nowo do okazania wierności człowiekowi, aby chory na progu śmierci „znów został otoczony miłością i solidarnością"21.

W kontekście marginalizacji śmierci warto zwrócić uwagę na przemiany, jakie zachodzą $w$ trosce o człowieka na początkowym etapie jego życia, w chwili narodzin. Szpitale przechodzą gruntowne modernizacje, aby móc zapewnić matce oraz całej rodzinie komfortowe warunki, umożliwiające w jak najlepszym otoczeniu narodzenie nowego życia. Dąży się nie tylko do zapewnienia jak najlepszych standardów zewnętrznych, ale również do zapewnienia odpowiedniej atmosfery poprzez zezwolenie na pobyt ojca czy osób towarzyszących. Coraz bardziej powszechne stają się porody rodzinne w warunkach szpitalnych, a nawet w warunkach domowych. Powstaja prywatne kliniki, kompleksowo przygotowane do stworzenia komfortowych warunków umożliwiających przyjście na świat dziecka. Profesjonalizm skupia się jednocześnie na działaniach stricte medycznych oraz na przygotowaniu właściwego dla danej osoby standardu zewnętrznego ${ }^{22}$. Przejawia się to w dostosowaniu odpowiednio pomieszczenia, począwszy od koloru ścian, wygodnych mebli, oświetlenia, muzyki, napojów, pożywienia, możliwości posiadania ulubionych ubrań czy pościeli, a skończywszy na najwyższej jakości sprzęcie medycznym.

Zważywszy na fakt, że śmierć jest ostatnim etapem życia, domaga się ona podobnej celebracji jak narodziny. Zapewnienie niezbędnych warunków do godnego umierania staje się zatem podstawowym wymogiem cywilizacyjnym we współczesnym świecie. W kształt negatywnego podejścia do umierania wpisują się postawy społeczne wobec śmierci, wypierające ze świadomości ostatnią fazę życia. Często rodzina ceduje możliwość towarzyszenia w ostatniej chwili życia na placówki opiekuńcze czy medyczne. Zapewnia potrzebne środki, alienując się jednocześnie od kłopotliwego problemu śmierci, wynika to zazwyczaj z braku odpowiedniego przygotowania i wsparcia. W obecnym czasie człowiek nie radzi sobie z procesem przemijania i odchodzenia z tego świata, spychając go na margines pośród wielu spraw, które wydają się ważniejsze do spełnienia ${ }^{23}$.

\footnotetext{
${ }^{20}$ Por. EV 31.

${ }^{21}$ Jan Paweł II, „Godność człowieka umierającego”, nr 3.

${ }^{22}$ Por. Wojciech Guzikowski, Porody rodzinne we wspótczesnym położnictwie (Wrocław: Akademia Medyczna, 2002), 24.

${ }^{23}$ Por. Sak, Wielowymiarowość postrzegania choroby w kontekście przekonań zdrowotnych, 56-8.
} 
Nastawienie współczesnej cywilizacji do problemu śmierci i człowieka umierającego określa Szczeklik: „Dla śmierci nie ma już miejsca w świecie, który zachorował na wieczną młodość. Choć do znalezienia eliksiru młodości jeszcze nam daleko, to śmierć już wyparliśmy z naszych myśli poza świadomość. Odmawiamy jej prawa bytu. O śmierci się nie mówi"24. Przyjmując takie podejście do przemijania i odchodzenia z tego świata, ludzie alienują się od sytuacji, w których powinni podjąć wezwanie do towarzyszenia człowiekowi w obliczu śmierci. Chętnie wypierają i usuwają do podświadomości proces przemijania oraz śmierć.

\section{UMIERANIE W CZASACH PANDEMII}

Na kanwie poruszanej kwestii towarzyszenia człowiekowi w obliczu śmierci warto przytoczyć subtelny paradoks prawny. Dziś już nikt nie wyobraża sobie możliwości pozostawienia dziecka samego w warunkach szpitalnych bez opieki rodzicielskiej, nawet w obliczu pandemii. Ograniczenia odwiedzin w placówkach szpitalnych w czasie pandemii nie moga zagrażać relacjom pacjentów z ich bliskimi, szczególnie dotyczy to osób niesamodzielnych, obłożnie chorych czy umierających. Sytuacja pandemiczna wymaga zastosowania nadzwyczajnych środków ostrożności, mimo to konieczne jest umożliwienie rodzinie sprawowania opieki nad pacjentami, którzy są w obliczu śmiertelnego zagrożenia. Szpitale mogą i powinny wprowadzać konieczne ograniczenia zabezpieczające, niemniej nie mają prawa do całkowitego zakazu bezpośredniego kontaktu, a tym samym do uniemożliwiania sprawowania opieki nad osobami chorymi, a w szczególności niesamodzielnymi i wymagającymi pomocy. Postulat ten przybiera formę alarmu w obliczu zbliżającej się śmierci osób najbliższych oraz dramatu przeżywanego sytuacją izolacji i braku kontaktu ${ }^{25}$.

Prawo pacjenta do towarzyszenia osoby bliskiej reguluje ustawa z 6 listopada 2008 r. o prawach pacjenta i Rzeczniku Praw Pacjenta. Prawa te w pierwszym rzędzie zapewnia Konstytucja Rzeczypospolitej Polskiej w art. 63 ust. 3: „Władze publiczne są obowiązane do zapewnienia szczególnej opieki zdrowotnej dzieciom, kobietom ciężarnym, osobom niepełnosprawnym i osobom w podeszłym wieku".

\footnotetext{
${ }^{24}$ Andrzej Szczeklik, Katharis. O uzdrowicielskiej mocy natury i sztuki (Kraków: Wydawnictwo Znak, 2002), 106-7.

${ }^{25}$ Por. Nagórny, Wartość ludzkiego życia, 291-6.
} 
Według ustawy w sytuacji zagrożenia epidemicznego lub ze względu na wymagania zdrowotne innych osób dopuszcza się ograniczenie odwiedzin, jednak zastosowane restrykcje nie mogą rodzić poważnego zagrożenia dla więzi pacjentów oraz ich bliskich. Sytuacja staje się newralgiczna, gdy stan osoby hospitalizowanej pogarsza się na tyle, że nie może sama napić się wody, odebrać telefonu, a tym samym zaspokoić podstawowych potrzeb życiowych. Deficyt samoopieki chorego pogłębia się w sytuacji niewystarczającej liczby personelu medycznego, którego pomoc ogranicza się do wykonywania niezbędnych procedur medycznych. Prawo pacjenta do relacji z bliskimi osobami staje się kluczowe do uregulowania w obliczu przedłużającej się sytuacji pandemicznej. Wymaga to zastosowania szczególnych środków ostrożności, wykonania dodatkowych testów i przeszkolenia osób starających się o uzyskanie pozwolenia na odwiedziny chorego w szpitalu, lecz w sytuacji wyjątkowej, jaka jest umieranie, umożliwia towarzyszenie najbliższej rodzinie ${ }^{26}$.

Obecność rodziny przy osobie umierającej jest doświadczeniem bardzo istotnym dla obu stron. Trudno znaleźć słowa, które opiszą ból rozstania, trudno też znaleźć rady, które uczynią lżejszą tę szczególną sytuację. Jest to specyficzne i szczególne wyzwanie dla najbliższych osób, które podejmują się obecności przy umierającym, a jednocześnie staje się ważną powinnością. Chorzy w stanie terminalnym obok bólu, braku kontroli nad własnym ciałem, ponad wszystko przeżywają lęk przed samotnością i opuszczeniem² ${ }^{27}$.

\section{FAZY ODCHODZENIA CZŁOWIEKA Z TEGO ŚWIATA}

Uczestniczenie w ostatnich chwilach życia wymaga wiedzy i pewnych umiejętności, aby towarzyszyć w profesjonalny sposób w procesie umierania. Warto zatem wiedzieć, jakie są symptomy odchodzenia i w jaki sposób towarzyszyć bliskiej osobie. Należy pamiętać, że przebieg procesu umierania i sposób reagowania umierającego ma swoje etapy. W każdym z nich pojawiają się różne zachowania i związane z tym emocje, a ich przebieg, natężenie i kolejność nie jest taka sama. Etapy, które można wyróżnić w procesie umierania, to jedynie opisowe ujęcie wypływające z poznania empirycznego ${ }^{28}$.

\footnotetext{
${ }^{26}$ Por. Sławomir Bukalski, „Śmierć i umieranie. Aspekty psychologiczno-pastoralne”, Studia Paradyskie 24(2014): 101-12.

27 Por. Andrzej Franciszek Dziuba, „Z problematyki etycznej chorych i umierających”, Chrześcijanin w Świecie 14(1982): 48-60.

${ }^{28}$ Por. Elisabeth Kübler-Ross, Rozmowy o śmierci i umieraniu, tłum. Irena Doleżał-No-
} 
Najbardziej trudnym do przyjęcia i zaakceptowania przez chorego jest fakt nadchodzącej śmierci. Chory czuje się jeszcze w miarę dobrze i jest głęboko przekonany, że z każdą pojawiającą się nową dolegliwością poradzi sobie zespół medyczny, który do tej pory podejmował leczenie z dobrym skutkiem. Jest to czas, kiedy lekarze wykonując kolejne badania, dochodzą do wniosku, że już nic więcej nie mogą zrobić w procesie leczenia i przyznają pacjentowi status terminalnie chorego. Sytuacja ta wiąże się z podwójnym, bardzo krytycznym momentem dla lekarza. Przyjmuje fakt swoistej porażki i bezsilności wobec własnych działań, a jednocześnie staje w obliczu trudności przekazania tej informacji pacjentowi i jego rodzinie. Może też przyjąć postawę przemilczenia lub unikania rozmów na temat pogarszającego się stanu zdrowia. Chory domaga się kolejnych działań leczniczych, a lekarz nie potrafi w sposób kompetentny przekazać informacji o wyczerpaniu środków i stanie zdrowia ${ }^{29}$.

W procesie odchodzenia choremu często towarzyszy niepewność, przeżywa on wątpliwości odnośnie do przebiegu leczenia. Czuje się coraz słabszy, przeżywa frustracje dotyczące powrotu do zdrowia oraz jest zaniepokojony dolegliwościami wskazującymi na permanentne osłabienie sił witalnych. Pojawiają się momenty lęku i smutku przeplatane nadzieją i oczekiwaniem na cudowną poprawę ${ }^{30}$. Cierpiący zauważa wprawdzie pewne sygnały śmiertelnego zagrożenia, ale za wszelką cenę próbuje je spychać do podświadomości, podważając przy tym kompetencje zajmującego się nim lekarza. Po tym czasie chory może przejść w stadium zaprzeczenia ${ }^{31}$. Wypiera ze swej świadomości bliski kres życia poprzez swoje zaktywizowane zachowanie. Snuje plany na przyszłość, kalkuluje, co jeszcze dokona i jakie spełni marzenia, gdy tylko poprawi się jego stan zdrowia. Jest to sposób ucieczki od rzeczywistości i negowania istniejącej sytuacji, choć używa wprost stwierdzeń „to przecież nie może być prawda, że umieram”, czy „na pewno da się jeszcze coś zrobić”. Chory nadal poszukuje różnorodnych sposobów wyjścia $\mathrm{z}$ doświadczanej bezsilności i braku poprawy zdrowia. Na tym etapie w relacjach $\mathrm{z}$ chorym należy unikać współuczestnictwa w kreowaniu zaprzeczenia, ważne jest nato-

wicka (Poznań: Wydawnictwo Media Rodzina, 1979), 28-36. Przedstawione etapy przeżyć psychiczno-duchowych w okresie umierania zostały sformułowane na bazie opracowań KüblerRoss oraz wzbogacone o doświadczenia zdobyte na kanwie zawodowej. Jednak opisanych etapów nie należy traktować schematycznie, mogą się one pojawiać z przemienną kolejnością i przybierać bardzo indywidualną intensywność.

${ }^{29}$ Por. Reroń, Etyka w szpitalu, 193.

${ }^{30}$ Por. Kübler-Ross, Rozmowy o śmierci i umieraniu, 19-21.

31 Por. tamże, 55-60. 
miast wspieranie chorego i okazywanie cierpliwości w sposób delikatny, ale prawdziwy.

Kolejną reakcją chorego w obliczu umierania może być bunt i agresja. Uczucia te występują czasem naprzemiennie z reakcją niepewności i zaprzeczenia. Nawet w okresie pogodzenia się z bliskością śmierci, chory może odczuwać nachodzące go fale buntu. Manifestacja buntu może przybierać formy szukania winnych i faktów, które spowodowały zaistniałą sytuację, a także reakcje samooskarżania i wyrzutów z powodu uczynionego wcześniej zła lub niespełnionego obowiązku ${ }^{32}$. Faza reagowania buntem wystawia na wyjątkową próbę miłość i wyrozumiałość osób towarzyszących w procesie umierania. Unikanie interakcji poprzez cierpliwe wysłuchiwanie może poprowadzić bliskiego do oczyszczenia, poprzez przyjęcie postawy przebaczenia i zaakceptowania swojej sytuacji.

Inną formą przeżywania procesu umierania jest targowanie się. Chory, nie akceptując postępującego procesu odchodzenia, dochodzi do kresu możliwości radzenia sobie samemu, doświadcza bezsilności i bezradności. Zaczyna zatem składać różne obietnice w zamian za nadzieję odzyskania zdrowia. W tym marazmie i niemocy rozpoczyna się dramatyczny targ o dalsze życie ${ }^{33}$. Składane deklaracje poprawy swojego dotychczasowego postępowania oraz wyszukiwanie przewinień, by za nie żałować, mają jeden cel: przedłużenie ziemskiego bytowania. W toku targowania się z losem możliwe jest poproszenie o pomoc duszpasterza w celu rozmowy, która wyjaśni nurtujące chorego dylematy, ukierunkuje poczucie winy, otworzy serce na nadzieję życia wiecznego. Zaspokojenie potrzeb duchowych związanych z praktyką religijną chorego przyczynia się w istotny sposób do osiągnięcia równowagi psychicznej i duchowej. Zwlekanie $\mathrm{z}$ posługą sakramentalną związane jest $\mathrm{z}$ fałszywą ochroną ciężko chorego przed tematem umierania i śmierci, a w konsekwencji może być pozbawieniem umocnienia jego wiary, nadziei i miłości w procesie umierania.

Po etapach bezskutecznej walki o dłuższe życie chory przechodzi w stan depresji. Pojawia się ona u większości świadomych swojej skrajnej sytuacji ciężko chorych osób ${ }^{34}$. Przejawem depresji może być apatia, niechęć do rozmowy, psychiczne poddanie się, zaprzestanie aktywności, odmowa przyjmowania leków, a nawet posiłków. Reakcje depresyjne może dodatkowo

\footnotetext{
32 Por. tamże, 66-72.

33 Por. tamże, 96.

${ }^{34}$ Por. tamże, 100-25.
} 
pogłębić niemożność podjęcia wypełnianych ról społecznych oraz realizacji misji życiowej. Na tym etapie przychodzi czas na pocieszenie, towarzyszenie poprzez obecność, pomoc w spełnianiu obowiązków. Depresyjne zachowania wypływające $\mathrm{z}$ bezsilności wobec zbliżającej się śmierci stają się katalizatorem i narzędziem przygotowującym do utraty wszystkiego, co człowiek w życiu kochał i posiadał. Dramat straty i odchodzenia może przerodzić się w chwile pożegnania i nadziei.

$\mathrm{W}$ ostatniej fazie procesu umierania następuje pogodzenie się $\mathrm{z}$ faktem nadchodzącej śmierci ${ }^{35}$. Może ono przybierać u niektórych chorych formę pragnienia śmierci jako wyzwolenia ze względu na ogrom doświadczanego bólu i cierpienia lub jako poczucie spełnienia życiowych zadań. Bardzo ważnym elementem towarzyszenia na tym poziomie jest poznanie potrzeb oraz spełnienie próśb umierającego jako ostatniej woli. Niektórzy śmiertelnie chorzy pragną przekazać w tym czasie życzenia i wskazówki dotyczące okresu po śmierci. Kluczowym elementem tej fazy odchodzenia jest czas na pożegnanie, przekazanie ważnych przesłań duchowych, a przede wszystkim staje się ona przestrzenią intensywnych przeżyć religijnych.

\section{UMIEJETNNOŚCI PRZYDATNE W TOWARZYSZENIU UMIERAJĄCEMU}

Obecnie myśl o śmierci spychana jest na margines świadomości. Kiedyś ludzie umierali $\mathrm{w}$ domu $\mathrm{w}$ atmosferze rodzinnego ciepła i miłości, otoczeni najbliższymi. Towarzyszenie umierającemu w domowych warunkach pozwalało przeżywać śmierć najbliższych jako swoiste misterium. Na łożu śmierci chorzy mieli okazję ostatni raz pożegnać się z bliskimi, przekazać ostatnią wolę, był to również czas na wybaczenie i pojednanie, intymne wyznania oraz udzielenie błogosławieństwa. Umierający nie byli samotni i opuszczeni, otoczeni troskliwą miłością rodziny odchodzili pełni nadziei zapewnieni o pamięci i modlitwie. Wraz ze zmianami współczesnej mentalności i rozwojem medycyny miejscem ostatniego pożegnania staje się szpital, klinika czy hospicjum. Moment śmierci zastaje chorych w samotności i opuszczeniu wśród zabieganego personelu medycznego. Rodzina szuka sposobów alienacji od udziału w końcowych chwilach życia członka rodziny, krewni rzadko towarzyszą chorym niosąc im ulgę swoją obecnością, pociechą, dobrym słowem

\footnotetext{
${ }^{35}$ Por. tamże, 125-130.
} 
i modlitwą ${ }^{36}$. Działania rodziny ograniczają się do załatwienia formalności związanych ze zgonem i załatwianiem pogrzebowych spraw. Współczesna postawa społeczeństwa wobec umierania doprowadziła do deformacji obrazu śmierci, a w efekcie końcowym do tanatofobii - panicznego lęku przed śmiercią.

W opiece nad osobą umierającą ważne jest posiadanie pewnych umiejętności przydatnych $\mathrm{w}$ towarzyszeniu ${ }^{37}$. Konkretne wskazania sposobu postępowania rodziny $\mathrm{w}$ czasie odchodzenia najbliższej osoby może $\mathrm{w}$ istotny sposób pomóc w przełamaniu lęku i izolacji.

U kresu życia chory jest często osłabiony i niezdolny do samodzielnego zaspokajania potrzeb, dlatego umiejętność odczytywania sygnałów pozawerbalnych pozostaje jedynym sposobem komunikacji. Wrażliwość i uważna obserwacja pozwolą właściwie odczytać i zrealizować ostatnie pragnienia osoby umierającej. Końcowe dialogi i relacje odbywają się poprzez uścisk ręki, spojrzenie, ruch głowy, grymas twarzy, reakcje na otoczenie. Właściwe odczytanie komunikatów pozawerbalnych pozwoli ulżyć w bólu, zaspokoić pragnienie, zmienić pozycje czy zgasić światło. Interpretacja gestów chorego umierającego nie jest łatwa do odczytania, jednak poprzez troskliwą obecność możliwa do zrealizowania, a tym samym dająca ulgę w cierpieniach fizycznych i emocjonalno-duchowych.

Innym istotnym elementem towarzyszenia umierającemu jest zapewnienie wsparcia emocjonalnego i duchowego. Odczuwana często przez chorych utrata godności i bezsilność, wynikająca z utraty kontroli nad własnym ciałem, poczucia bycia ciężarem dla najbliższych oraz przeżywana samotność staje się szczególnym wyzwaniem w opiece. Nasilające się cierpienia egzystencjalne i duchowe oraz dramat rozstania potęgują niepewność i zwątpienie nawet u osób głęboko wierzących. Nieodzowna w tym okresie jest otwartość na potrzeby duchowe i religijne. Warto zaproponować modlitwę indywidualną, wspólnotową czy wykorzystać możliwości mediów oraz zapewnić posługę sakramentalną. Ważne jest wybieranie tych form modlitwy, które są bliskie

\footnotetext{
${ }^{36}$ Izabela Chmiel, Katarzyna Kochan, Zygmunt Pucko i Tomasz Brzostek, „O niektórych dylematach przygotowania do śmierci”, w W drodze do brzegu życia, red. Elżbieta KrajewskaKułak, Cecylia Regina Łukaszuk, Barbara Jankowiak, t. 5 (Białystok: Uniwersytet Medyczny, 2008), 62-3.

${ }^{37}$ Poniższe umiejętności przydatne w opiece nad chorym umierającym zostały opisane na podstawie materiałów Fundacji TZMO Razem Zmieniamy Świat, w projekcie edukacyjnym Damy Radę, która zajmuje się pomocą w towarzyszeniu umierającemu, www.damy-rade.info, 9.01.2021.
} 
umierającemu, np. różaniec, koronka, psalmy, czytanie Pisma Świętego, pieśni religijne, muzyka medytacyjna czy zapalenie świecy.

Nie mniej ważną umiejętnością jest zadbanie o wytworzenie właściwego klimatu dla osoby odchodzącej. Najbardziej właściwym miejscem dla chorego w obliczu śmierci jest atmosfera domu rodzinnego. Obecność bliskich osób, rozumiejących umierającego, jak również przebywanie w pomieszczeniu znanym choremu pozwoli zapewnić poczucie bezpieczeństwa. Jeżeli stan zdrowia chorego wymaga hospitalizacji lub opieki hospicyjnej, to również w tym miejscu należy wytworzyć domowy klimat. Czasem wystarczy zdjęcie osób najbliższych, ustawienie religijnego obrazka, podanie różańca, ulubiona poduszka pod głowę, koc do przykrycia czy serwetka na stolik, te pozornie drobne elementy pozwolą zmienić placówkę $\mathrm{w}$ pomieszczenie $\mathrm{z}$ domową atmosferą. Ważne jest również zwrócenie uwagi na zapewnienie właściwego oświetlenia pomieszczenia, dostosowanego do potrzeb umierającego. Śmierć nie musi być tematem związanym z lękiem czy porażką medyczną, a uwolnienie jej od tabuizacji i wypierania ze świadomości może stać się wydarzeniem rodzinnym i religijnym naznaczonym nadzieją i troskliwą miłością ${ }^{38}$.

Refleksja moralna nad towarzyszeniem człowiekowi w obliczu śmierci jest w obecnych czasach szczególnie potrzebna. $\mathrm{Z}$ jednej strony proces umierania spychany jest na margines życia poprzez wypieranie go ze świadomości. $\mathrm{Z}$ drugiej strony pragnienie bycia zdrowym, sprawnym, młodym w zsekularyzowanym świecie wolności i samodecydowania niemal o wszystkim w zderzeniu ze śmiercią rodzi lęk i zmowę milczenia na ten temat. W efekcie umieranie i śmierć przeżywane są instytucjonalnie i prawnie, co determinuje możliwość interakcji między umierającym a rodziną. Z wydarzenia rodzinnego ostatnie chwile życia przekształcają się w wydarzenie medyczne, pomijające prawdziwe potrzeby osoby umierającej i jej najbliższego otoczenia. Aspekt medykalizacji śmierci nabiera szczególnie rygorystycznych rysów w dobie pandemii. Umierający człowiek staje się problemem, który przychodzi nie w porę i rodzi zaskoczenie. Alternatywą prowadzącą do godnego przeżywania umierania i humanizacji śmierci jest rozpoczęcie procesu otwierania się na

\footnotetext{
${ }^{38}$ Por. Antonina Ostrowska, „Znaczenie postaw wobec śmierci”, Medycyna Paliatywna w Praktyce 10(2016): 46-7.
} 
problemy odchodzenia z tego świata poprzez akceptację śmierci jako ostatniej fazy życia oraz podjęcie trudnego wyzwania towarzyszenia umierającemu.

\section{BIBLIOGRAFIA}

Anders, Janusz. „Problemy medyczne i etyczne stanów terminalnych człowieka”. W Bioetyka personalistyczna, red. Tadeusz Biesaga. Kraków: Wydawnictwo Naukowe PAT, 2006.

Aszyk, Piotr. Granice leczenia. Etyczny problem odstapienia od interwencji medycznych. Warszawa: Rhetos, 2006.

Bartoszek, Antoni. Człowiek w obliczu cierpienia i umierania. Moralne aspekty opieki paliatywnej. Katowice: Księgarnia św. Jacka, 2000.

Bołoz, Wojciech. „Eutanazja w kontekście praw człowieka”. W Bioetyka personalistyczna, red. Tadeusz Biesaga. Kraków: Wydawnictwo Naukowe PAT, 2006.

Bukalski, Sławomir. „Śmierć i umieranie. Aspekty psychologiczno-pastoralne”. Studia Paradyskie 24(2014): 101-12.

Chmiel, Izabela, Katarzyna Kochan, Zygmunt Pucko i Tomasz Brzostek. „O niektórych dylematach przygotowania do śmierci”. W W drodze do brzegu życia, red. Elżbieta KrajewskaKułak, Cecylia Regina Łukaszuk, Barbara Jankowiak, t. 5, 59-64. Białystok: Uniwersytet Medyczny, 2008

Dziuba, Andrzej Franciszek. „Z problematyki etycznej chorych i umierających”. Chrześcijanin w Świecie 14(1982): 48-60.

Guzikowski, Wojciech. Porody rodzinne we wspótczesnym położnictwie. Wrocław: Akademia Medyczna, 2002.

Jan Paweł II. Encyklika o wartości i nienaruszalności życia ludzkiego „Evangelium vitae” (25.03.1995). Rzym, 1995.

Jan Paweł II. „Godność człowieka umierającego”. Przemówienie do uczestników zgromadzenia ogólnego Papieskiej Akademii „Pro Vita” (27.02.1999). L'Osservatore Romano (pol.) 20, nr 3(1999): 47-9.

Katechizm Kościoła Katolickiego. Poznań: Pallottinum, 1994.

Nagórny, Janusz. Wartość ludzkiego życia, red. Krzysztof Jeżyna, Jerzy Gocko, Wojciech Rzepa. Lublin: Wydawnictwo KUL, 2009.

Kübler-Ross, Elisabeth. Rozmowy o śmierci i umieraniu. Tłumaczenie Irena Doleżał-Nowicka. Poznań: Wydawnictwo Media Rodzina, 1979.

Ostrowska, Antonina. „Znaczenie postaw wobec śmierci”. Medycyna Paliatywna w Praktyce 10(2016): 41-7.

Reroń, Tadeusz. Etyka w szpitalu. Diakonia - Medycyna - Duszpasterstwo. Wrocław: Papieski Wydział Teologiczny, 2020.

Sak, Jarosław. Wielowymiarowość postrzegania choroby w kontekście przekonań zdrowotnych i poczucia sensu życia. Lublin: Uniwersytet Medyczny, 2013.

Sobór Watykański II. Konstytucja duszpasterska o Kościele w świecie współczesnym Gaudium et spes (7.12.1965). W Sobór Watykański II. Konstytucje. Dekrety. Deklaracje, 104-66. Poznań: Pallottinum, 2002. 
Szczeklik, Andrzej. Katharis. O uzdrowicielskiej mocy natury i sztuki. Kraków: Wydawnictwo Znak, 2002.

Wróbel, Józef. Człowiek i medycyna. Teologicznomoralne podstawy ingerencji medycznych. Kraków: Wydawnictwo Księży Sercanów, 1999.

\title{
TOWARZYSZENIE CZŁOWIEKOWI W OBLICZU ŚMIERCI ASPEKTY MORALNE
}

\author{
S t r e s z c z e n i e
}

Przedmiotem publikacji jest zagadnienie towarzyszenia człowiekowi umierającemu. Śmierć jako ostatnia faza życia ludzkiego jest niezaprzeczalnym faktem, a przejście do życia wiecznego stanowi niezwykle istotne wydarzenie dla osób wierzących. Szczególnym wezwaniem w obecnym czasie jest uczynienie z niej wydarzenia ludzkiego pośród procedur medycznych, lęków i marginalizacji. Rozpoznanie procesu umierania jawi się jako ważny element w rozpoczęciu przygotowania chorego do śmierci oraz towarzyszenia rodziny w tym misterium. W tym celu wskazano także na konkretne umiejętności przydatne w opiece terminalnej. W toku badań zwrócono również uwagę na odpowiedzialność personelu medycznego za przekazanie informacji o możliwości nadejścia śmierci oraz na uwrażliwienie chorego i jego rodziny na czas umierania. Przyjęcie śmierci i akceptacja odchodzenia $\mathrm{z}$ tego świata staje się podstawową wskazówką przywrócenia temu wydarzeniu humanistycznego wymiaru pośród procedur medycznych zwłaszcza w obliczu szczególnego przejawu industrializacji umierania, którym stał się czas pandemii, uniemożliwiający właściwe relacje rodziny z chorym.

Słowa kluczowe: humanizacja śmierci; tanatofobia, fazy umierania; towarzyszenie; umiejętności. 